HARM W. HOLLANDER and GEP J. MARSEILLE

\title{
EASY-TO-READ DUTCH: A NEW TRANSLATION FOR CHILDREN AND ADULTS
}

Drs. Hollander is a NT biblical scholar and researcher in the Biblework Department of the Netherlands Bible Society, and Mr. Marseille is a staff member in the Publishing Department

In 1965 the Netherlands Bible Society started publishing a new series of simply worded Bible stories which was originally meant for mentally handicapped people. This series, called Wat de Bijbel ons vertelt, "What the Bible tells us", now includes 25 volumes. The Bible stories found here cannot be called translations in the full sense of the word, because many elements of the original text are omitted. But unlike many children's Bibles, they do not add new (religious) elements not present in the text proper. The series soon became popular and it proved to appeal also to young children up to an age of six or seven years.

On another level, the Dutch New Testament common language translation, Groot Nieuws voor $U$, tries, like all the other common language translations, to appeal to modern people. It is designed for both church-goers and those who have drifted away from the churches and the traditional translations of the Bible which are now rather difficult to read and understand. Readability tests according to the Flesch method and its revised Dutch model (the Flesch-Douma formula), however, have proved that even this common language translation has not completely got away from the use of difficult words, constructions, phrases and sentences, elements that greatly affect the ease of reading.

Although the readability of this translation is much better than that of older translations, it is still not suitable for people with a reading age level of below 13 years. So, there seems to be a group of people for whom there are no Bible translations available: those who have a reading age level of 8-12 years, including both children of that age and also certain groups of grownups.

Firstly, with regard to children, this gap is usually (at least in Dutch Christian families) filled by children's Bibles, of which there are more than 25 different titles. But in recent years the value of many of these children's Bibles for the spiritual and religious growth of young people has been questioned. Many experts in this field think that at least some of these books, including the most popular ones, present a picture of the Bible which in many ways is not true to the real meaning of the Bible text. Objections of this kind have been summed up in a report published jointly by the Netherlands Bible Society and the Catholic Bible Foundation in 1972. We will not enter into that discussion here, but it is a fact that this report and the discussions it caused have contributed to the growing demand for a true and faithful translation of the Bible text itself that can be understood by children of the age of 8-12 years.

Secondly, we have found that in Western Europe, "reading age 8-12" includes not only children of that age but also many grown-ups. In the years just after 1970, we in the Netherlands used to think that "new reader programmes" were not appropriate to our situation, except for young children. 
Starting from Great Britain, however, large groups of Western Europeans have been "discovered", as it were, as "new readers". They are the people who cannot or do not read books with a reading age level of 13 years and upwards, often called "functional illiterates" and "habitual non-readers". Among these, we may also mention those who are handicapped in acquiring full reading ability, such as people born deaf. Another group of adults who find difficulty in reading books with a reading age level of above 12 years are those for whom Dutch is a second language. We think of migrant workers, South Moluccans, people born in Indonesia and Surinam, and so on.

Wishing to reach these groups of people, all having a reading age level of 8-12 years, with a translation of the Bible text, the NBS started in 1976 with a new translation project. Since then, four small books have been published: Samuel en Saul, giving a translation of chapters 1-15 of 1 Samuel; Saul en David (1 Samuel 16-31); Zo ging het met Jezus ("This happened to Jesus"), a translation of Matthew 25-27; and Jezus komt in de wereld ("Jesus comes into the world"), a translation of Luke 1.1-2.40. The last two of these have been produced as strips.

\section{SOME FEATURES OF THE NEW TRANSLATION}

For this project, which is called "eenvoudig Nederlands" (easy-to-read Dutch), some principles were adopted at the beginning.

1. First of all, Bible passages should be translated as a whole. Hardly any departure from this rule has been accepted in the course of the project. In 1 Samuel 1.1, for instance, just a few names have been omitted from Elkanah's list of ancestors. No concessions have been made to possible protests against translating "cruel" and "barbarous" passages for children, of which there are quite a few in 1 Samuel. For according to modern views, children usually find that kind of story less of a problem than grown-ups: the problem is that many parents and teachers "project" their own difficulties in accepting the Bible as it is into their views on teaching children. Since we do not give just short selected passages from the biblical stories about, for instance, David or Jesus, but translations of whole sections from the Bible, we do not need to include adjustments either at the beginning of a passage or as "bridge material". (As is done for instance by Heber Peacock and Barclay Newman in their Good News in Paper: see the October 1978 issue of The Bible Translator, pages 401-409).

2. Secondly, we should give a faithful translation of the text. The Bible text should be translated, not paraphrased. No elements which are not present or carried by the words of the text are allowed in the translation. As a translation principle, the method of translating meaning for meaning ("dynamic equivalence") has been accepted. Since we believe that "translating for children" should be "translating for children", we do not begin with our Dutch common language translation (for the New Testament), but we translate directly from the original languages. (This seems to be another important difference from the publication Good News in Paper, in which the Good News Bible is used as a starting point.) 
3. Thirdly, a translation with a reading age level of 8-12 years calls for some specific translation rules: sentences of no more than 10 to 12 words; very few negative phrases; by preference no passive forms; no idiomatic peculiarities; words of as few syllables as possible; no words of low frequency. (These are all elements that contribute to a high degree to the readability of a text.)

Two translation teams have been formed, one for the Old Testament and another for the New Testament. Each team is composed of a biblical scholar with experience in teaching religion to young people, who is responsible for the first draft, together with another biblical scholar as adviser, an educationalist, and a trained NBS staff member. The whole team is responsible for the final draft of the translation.

\section{FUTURE PLANS}

Translation work on the Old Testament started with the books of Samuel and will continue with the books of Kings. As for the New Testament, two selections have been published so far, one on Jesus' death and another on Jesus' birth. A translation of Luke and Acts is being prepared.

While the portions, that is the translations of 1 and 2 Samuel, 1 and 2 Kings, Luke, and Acts, are designed as books for children, the Easter and Christmas selections apply to grown-ups too, and have a more or less direct missionary function.

Over a few years we hope to evaluate the impact of this translation work. Then perhaps we shall be able to answer questions like whether it is the right sort of translation for the target groups, and whether the whole Bible should be translated in easy-to-read Dutch. We also hope to find out whether the same translation can be used by children and certain groups of adults, so that just a change of lay-out will make portions like Samuël en Saul suitable for these groups of grown-ups.

All these questions are still open. But one thing is certain: none of the existing translations of the Bible, not even the one in common language, can be fully understood by people with a reading age level of below 13 years. And that is the reason why the Netherlands Bible Society is going ahead with the project of a new translation in easy-to-read Dutch.

BARCLAY M. NEWMAN JR.

\section{"VERSES MARKED WITH BRACKETS . . ."}

Dr. Barclay Newman is a UBS Translations Research Associate resident in the USA

"Verses marked with brackets [] are not in the oldest and best manuscripts of the New Testament." This, or a similar statement, appears in the introductions to a number of modern translations of the New Testament. But it sounds strange to many devout Christians, who believe that the Bible has somehow remained intact, without change or alteration, throughout the 